\title{
Anti-Corruption Commissions: Lessons for the Asia-Pacific region from a proposed Australian Federal Anti-Corruption Watchdog ${ }^{1}$
}

\author{
By Marie dela Rama, UTS Business School, Sydney, AUSTRALIA ${ }^{2}$ and \\ Michael Lester, Long View Partners, Sydney, AUSTRALIA ${ }^{3}$
}

\begin{abstract}
This paper reviews the experience of anti-corruption commissions in the region and argues that the debate on the establishment of a national anti-corruption body in Australia is dependent on the country's political culture, institutions and elites. Corruption and integrity coexist and are conceived as the obverse and converse respectively, of a functional and dysfunctional system. Anti-corruption bodies in the Asia-Pacific region are compared against applicable global anti-corruption frameworks, policies and principles. The paper proposes a conceptual model for a National Integrity Ecosystem (NIE), premised on community values and trust and situates the Australian experience within such an ecosystem. A federal anticorruption watchdog is the missing piece in Australia's institutional infrastructure. Its acceptance and effectiveness requires difficult and sustained change in the underlying political culture of the country and its elites.
\end{abstract}

Keywords: Asia-Pacific, Australia, corruption, institutions, national integrity system

\section{Introduction}

Cui bono? Or who benefits? Anti-corruption watchdogs around the Asia-Pacific have been established after long drawn-out fights to establish public confidence and trust in their country's institutions, often against the entrenched, vested interests of powerful elites.

\footnotetext{
${ }^{1}$ We would like to thank our anonymous reviewers for providing constructive comments that helped refine the ideas explored in the several iterations of this paper.

${ }^{2}$ Corresponding author: marie.delarama@uts.edu.au; ORCID ID: oooo-ooo1-7879-4750; Scopus ID: 5468177660o; Twitter: @corpgovresearch. Marie dela Rama (PhD) is a Management Academic from UTS Business School, Sydney, Australia. Her research interests cover aged care, business ethics, corporate governance and corruption. Her most recent book is The Changing Face of Corruption in the Asia-Pacific (with Chris Rowley, Elsevier 2017).

3 Co-author: melester@yahoo.com; Twitter: @michaelezlester. Michael Lester (BE [Hons], BA, MEc) is Principal of Long View Partners, Sydney, Australia. He has extensive public policy experience as an economist having worked with central policy and line agencies in Australia at the federal and state levels. He has also worked with diplomatic status on environment issues at the OECD in Paris, as a trade representative for Australia in India and as an Investment Policy Adviser with the World Bank. Michael has travelled extensively on business including in the Asia Pacific region.
} 
The protracted debate and associated struggle to establish a federal anti-corruption watchdog in Australia echoes the experience of its neighbours and Asia-Pacific counterparts. Those with economic and political power have always been reluctant to share it. But the history of economic growth and development attests to the value of open institutions that provide equal opportunity and access for all, not just for existing vested interests (Acemoglu \& Robinson 2012).

This paper highlights the importance of building strong institutions backed by the force of political culture and legal systems which ensure that anti-corruption watchdogs have legitimacy in the eyes of community. A framework is proposed to define the context and boundaries of a national integrity ecosystem (NIE). A desk, literature survey of anticorruption commissions around the region and Australia was undertaken as a basis for summarising the state of play and experience of anti-corruption watchdogs in the Asia-Pacific region.

\section{Literature Review: Institutional theory and anti-corruption institutions}

As a form of human organising, institutions are the outcome of social and economic actions (Smelser and Swedberg 2005). Adam Smith, in his 1776 treatise, the Wealth of Nations, pointed out the importance of confidence in a state whereby there is a 'regular administration of justice', security in property, law and the enforcement of contracts. This is known generally as 'the rule of law'.

Across countries, political institutions reflect differing cultures of socio-economic, historical, judicial, political and religious relationships. These humanly devised constraints on the structure of human interactions and their respective enforcement mechanisms may be both formal and/or informal in character (North 1990). Informal constraints include norms of 
behaviour, convention and codes of conduct, and enforcement mechanisms, and are part of 'the heritage we call culture'. Formal constraints are the creation of the polity covering rules, laws, and constitutions: Institutions are the rules of the game. Indeed, institutions reflect society's concerns and in some cases, its need to adapt as they 'provide the incentive structure of an economy; as the structure evolves, it shapes the directions of economic change towards growth, stagnation or decline.' (North 1991: 1)

Institutional theory posits their continued existence and reason for being as social constructs that shape 'the means by which interests are determined and pursued' (Scott 1987: 508), or, decide who gets what, and when. Once established, institutions are 'products of interaction and adaptation; they become receptacles of group idealism; they are less readily expendable.' (Selznick 1957: 22)

There are three forces underlying an institution's establishment and continued existence: functional, political and social (Dacin et al 2002). Functional pressures seek to improve organizational performance; political pressures seek to redistribute power through institutions and are particularly in play when there is a change in political leadership; and finally, social pressures arise from the public's expressed needs for change consistent with the community's underlying values. As discussed in this paper, political and social pressures are the primary drivers in the calls for and establishment of independent anti-corruption commissions.

In its 2002 World Development Report, the World Bank Group emphasized that building institutions in government includes putting in place institutions that deal with corruption and taxation, alongside building institutions in civil society that advocate for freedom, transparency and anti-corruption (World Bank 2001).

Institution building is a good start, but they must also have appropriate mandates, be robust, well-resourced and independent so that they can effectively address issues of corruption and 
governance (Nye 1967; dela Rama 2017). The role of statutory and regulatory institutions is fundamental in order to prevent and address the opportunities for corruption. They can and should minimize the risks of politicization exercised in favour of vested interests, and elites within existing power structures and the status quo, whilst giving hope to those, from civil society especially, who demand accessibility, transparency, accountability and change to corrupt practices. In the case of the latter, the proliferation of social media has resulted in the wider public awareness of unsavoury practices (Widojoko 2017).

As dela Rama \& Rowley pointed out:

Institutional development to tackle corruption requires political will, a relatively depoliticized bureaucracy and a culture that is willing to be responsive and adapt to the changing needs of the country. (2017: 373)

Weak and ineffective institutions result in the populace being affected by corruption particularly minor or petty forms - in daily life (Proctor 2017). Where government agencies and officials are perceived to be corrupt, inefficient and under the sway of or captured by vested interests with privileged access, public trust in government and politics is eroded. This also contributes to the growth of the 'black or shadow economy' that seeks to operate outside 'the rule of law' (Schneider 2011) and, in some cases, to outward immigration (Chin 1999) and human trafficking (Guth 2010). Indeed, corruption in public institutions can also affect the very physical health of a country's citizens with the proliferation of infectious disease and antimicrobial resistance found to be related to the strength or weakness of a country's public institutions (Collignon et al 2018). The 'cancer of corruption' is not only metaphorical but also literal. This political disease is seen as the biggest barrier in improving public health in developing countries (Mackey 2016 et al). On a more philosophical and speculative 
interpretation, the proliferation of corruption may be symptomatic of a general disintegration and decline of a country's political system (Allan 2014).

In practice, the benefits and importance of good institutions and institutional strength are highlighted by the example of the Hong Kong Independent Commission Against Corruption (discussed later in this paper); its mandate empowers it to 'impartially and rigorously enforce the law at all times making corruption a high risk crime in Hong Kong. The corrupt will be pursued relentlessly irrespective of their background, status and position.' (Hong Kong ICAC 2017) Strong anti-corruption institutions enhance the triumvirate 'pillars' of government, economy and society, and contribute to the further strengthening of the integrity of the ecosystem as a whole. Strengthening these institutions, especially nascent ones, is pivotal in countries with a predatory government and/or 'crony capitalism' (Hutchcroft 1998). The next section proposes a framework outlining a political integrity ecosystem that places corruption within the systemic interaction of institutions, culture, values and trust.

\subsection{A National Integrity Ecosystem (NIE) Framework}

This paper argues that understanding political corruption and redressing it effectively- to ensure political integrity - must be done within the broad framework of a complex socioeconomic system. As such, in this conceptual paper, we propose the following research question:

What should a national integrity ecosystem (NIE) framework consider?

Systemic political corruption arises from an ethically degraded political culture (Rogow \& Laswell 1970); in the case of contemporary western democracies the now problematic values and beliefs underlying the neo-liberal market driven agenda of the 1980s have been exposed by untenable inequality and the collapse of political trust (Dine 2017; Allan 2014). 
Culture is given expression through, and interacts with, political institutions; changes in both variables are required to secure political integrity and a sustainable democracy. National culture reflects the intangible constituents that manifest themselves in the country's institutions. Hofstede's (1984) four dimensions of national culture find expression to varying degrees at an institutional level and within organizations. For example, countries in Asia that have a high power distance culture are characterized by organizations with greater centralization and enforced hierarchy: the superior-subordinate (such as a manager-employee or owner-manager) relationship is marked by strong dependency needs, autocracy or paternalism and acknowledgement of authority $(1984: 107,259)$ as opposed to undermining or even subjugation of authority in low-power distance cultures.

The collectivism/individualism dimension is also important in understanding the culture within the framework. Strong individualistic countries such as Australia emphasize the responsibility of the individual in their performance of duties as opposed to collectivist cultured countries such as South Korea whereby organizations emphasize the responsibility of group membership and group decision-making (1984: 171). Even countries that value conflict avoidance and social harmony (dela Rama 2011) can manifest a destructive culture if senior leaders engage or are perceived to engage in corrupt behaviour, leading to dysfunction. Conversely, if senior leaders emphasize transparent, accountable and trustworthy actions walking the talk so to speak - then the acceptable scope for bribery and other malfeasance is narrowed (Lee 2000: 647-648).

In answering our research question, we term our conceptual framework: the 'National Integrity Ecosystem' (NIE). As presented in Chart 1 this ecosystem has four principal and interacting components: national integrity; national corruption; political culture, and, institutions. They interact within a broad sphere of values and beliefs, domestic and international. Together they constitute a complex and adaptive ecosystem that bears on the 
level of political trust essential to the functioning of a democratic society. The chart below sets the broad conceptual framework for our paper.

\section{[Insert Chart 1 here]}

The main stakeholders in a NIE are the politicians and the community. In representative democracies, the politicians are elected by the community and thereby represent the power vested in the people and delegated to the politicians. These stakeholders interface and interact through the political system of a country where national culture, trust and values are reflected or become embedded in the country's institutions.

Domestic and international events are part of, and have an influence on, the integrity ecosystem whether through formal or informal channels. Formal channels may include institutions, international forums and agreements; while informal channels may be through elite/oligarchical networks in business and politics or civil society activism and social media, for example as represented by broad developments such as globalisation, neo-liberalism and more recently, populism.

This framework suggests that any individual initiative on integrity and corruption, unless it is understood and developed as a component of a much larger ecosystem, is likely to be ineffective; each component interacts with the others, often in unforeseen and unpredictable ways. At the heart of the integrity ecosystem is the process of 'politics'. Its role is to mediate democratically (in the public good) between political institutions/community (right circle) and political culture/politicians (left circle) so as to maintain a sustainable balance between community values and trust (small eggs) in politicians. This broad setting includes in the big, enclosing egg shape (with the inset labels in Chart 2 reflecting the broader ecosystem viewed from an Australian perspective) a wide range of international and domestic drivers and trends shaping national systems. 


\subsection{Political integrity and corruption}

It is helpful to consider integrity and corruption as 'two sides of the same coin' or as the 'reverse faces of Janus', interacting and in tension with each other along a spectrum. This allows our driving concern about growing 'political corruption' and its implications for declining trust in politics to be regarded as a deviation from a desired norm namely, political integrity. It provides a conceptual benchmark against which we can measure the extent of corruption at any given time or place by the gap between the values and practices of integrity and corruption.

In the first instance, integrity may be thought of as politicians complying to obligations set down in official codes of conduct and ethics, and more generally, as their adhering to the public-service ethos underpinning these usually non-statutory codes. But relying on the personal and even collective integrity of public officers is not a complete answer. Important as these 'positional duties' certainly are, the concept of political integrity arguably invokes a broader 'commitment to principled causes' (Hall 2018). Integrity requires the furthering of these deeper political commitments while avoiding malfeasance or misconduct. Such assessments of political integrity typically require to be made over a long train or series of political actions over time rather than a focus on one-off actions.

Integrity is seen as an increasingly rare commodity, especially in politics, and in an environment of systemic non-integrity, politicians who aspire to live to high standards of accountability often do not last. Where private and public sectors become closely intertwined, a political career is invariably an uncertain and less rewarding undertaking without the right links to the business world, providing fertile soil for privileged access to government decision-makers, for career development on leaving public office, and even for 'black letter' bribery and corruption, In such environments, with outsourcing and privatization of large 
public investments and often discretionary regulatory powers, corruption can also reduce economic growth (Tanzi 1998).

The concept of 'political corruption', broadly defined as satisfying private interests at the expense of the public interest, raises fundamental questions about underlying value judgments of the distinction between private and public arenas and their objectivity. There is a tendency to adopt a 'Western perspective' or conceptual relativism in judging political corruption that maintains an illusion of the purity between public and private domains (Bratsis 2014). This norm has evidently varied over history, societies and geography, and in particular, has seen a significant shift since the 1980s. From Margaret Thatcher's 'there is no such thing as society', and Ronald Reagan's 'government is the problem not the solution', the heralding of the neoliberal age (Dine 2017) has seen a general shift in politics away from the 'middle ground' towards the 'right'. Wide political acceptance of the market-based, profitdriven, deregulated, small-government cultural ethos has marked a shift in 'political corruption'. In particular, this has been reflected in a public perception that politicians have become self-interested and captive of vested interests thereby opening up a wide gap in institutional and political trust. In particular, anti-corruption institutions are now perceived as lagging behind this citizen perspective.

\subsection{Political trust}

Popular trust is the belief that the political system will deliver preferred outcomes even if left unattended (Shi 2001). The origins of political trust have been sought in theories of both cultures and institutions (Mishler \& Rose 2001); the former emphasize the endogenous, or internalized set of determinants of trust while the latter emphasize the exogenous, or imposed set of determinants. Ma and Yang (2014) argue that political trust stems from social trust. It is independent in the short run of outputs and performance and is an important determinant of 
the stability of the system. However, it is dependent 'on the performance of government and institutional arrangements' especially in authoritarian regimes in East Asia to reform institutions, promote governance and control corruption (2014: 339). That is, if trust is lost then the political system becomes less stable.

Indicators of instability may include rampant corruption, scandals, growing role of independents in democracies, minority governments, shifting coalitions, changing leaderships, frequent elections, and other elements with a growing appeal to populism, authoritarianism and nationalism in an attempt to restore stability. Political trust is important too in that it provides governments with room to move, to be flexible and adaptive to changing circumstances and needs.

\subsection{Political culture and values}

Political culture is the set of underlying collective assumptions, attitudes, sentiments, beliefs and values that give structure and order to a political system and its processes, and that determine political rhetoric and behaviour (Smith 2001). It is an accepted if disputed empirical concept that is transmitted and generally remains unchanged over the short term.

The term 'political culture' first appeared in modern political science in the late 1950s and early 1960s to denote the pattern and orientation of political actions within a political system (Almond 1956, 1963) and is associated with the modernization theory of democracy (Parsons 1971). The concept refers to the psycho-sociological limits or conditions within which political agents and their belief structure of a given polity operate and, outside of which structure political action would be incoherent (Bove 2002).

In its contemporary revival it has been described as a 'political rubric' in light of its continued weakness as a concept and theory namely, difficulty in disentangling sub-cultures 
such as political elites; and difficulty in its interactions with institutions and policy attributes to demonstrate a propensity for certain types of political outcomes (Reisinger et al. 1995). Differing cultural values and beliefs held by politicians mean that their actions are determined by their mediating the different values or meanings that they place on those actions rather than by a direct response to the issues in hand. They react to the same stimuli in different ways according to their values. Political culture has a significant impact on political trust and it cannot be reduced to the effects of institutions and structures. In other words, political culture runs deep and cannot be legislated or created to increase political trust. Their underlying values and beliefs mediate and create a lag in the change of political culture.

On the theoretical side, values and beliefs are often treated differently (Alesina \& Giuliano 2015). Beliefs about the consequences of actions can be manipulated by transmission or by experiment; values are seen as a more enduring primitive phenomenon. As in psychology, culture emphasizes the role of emotions in motivating human behaviour. The rise of political 'culture wars' in Australia illustrates the nature and often divisive impact of such valuesdriven politics. These two interpretations of culture, as values or beliefs, are not mutually exclusive; they can interact systematically with each other as well as with institutions to change over time (Benabou 2008).

In the case of Australia, these influences include ideology, federalism, liberal democratic principles, Westminster tradition and party government (Singleton et al. 2014) and five particular dimensions of political culture have been identified: attitudes to reliance on government; responsiveness of government; citizen duty; authoritarianism; and, federalism (Bean 1993).

The ethical challenge for developing effective anti-corruption measures turns on identifying and establishing improper motives, intentions, interests and benefits between actors involved 
in corruption, as well as providing evidence of damage to public interest. This is compounded at times when the political culture has been shifting as it has in recent decades. The process of corrupt behaviour can become subjective and difficult to prove in court; when not proven objectively, such actions can only be understood and treated as undermining trust, unethical, inefficient or even ineffective but not technically or legally as corrupt.

\subsection{Politics and institutions}

There is strong support for institutional explanations of political trust particularly at the micro, individual level, rather than at the macro, societal level (Mishler \& Rose 2001). Under this view there is grounds for cautious optimism about the potential for nurturing popular trust by the establishment of new institutions that promote democratic principles and political culture.

The formal, institutionalized approach to tackling corruption avoids subjective approaches that require motives and intentions to be identified. They focus on the criterion of 'legitimate' actions that comply with due democratic legislative process that includes generality, autonomy and publicity (Thompson 1993). Corruption or inappropriate actions are defined as detrimental to the democratic process as a result of specific relations between the actors involved. Accordingly, political or private gains are not corrupt in themselves; they are only deemed corrupt if obtained by avoiding democratic process controls.

The narrower idea that the ethics of a situation are based on the specifics of an actual case is known as 'casuistry' and is often dismissed on the grounds that culture, stories and ethics cannot be reduced to generalizing equations (Lanchester 2018). It is a method of applied ethics and jurisprudence originally applied to quibbling or evasive ways of dealing with 
difficult cases of duty. It is often characterized as a critique of principle - or rule-based reasoning. ${ }^{4}$

Nevertheless, there is increasing pressure for political transparency and accountability to be institutionalized, with rules on full disclosure, freedom of information, public declaration of assets, and an open invitation to public scrutiny, with rules and regulations governing conflicts of interest and requiring full disclosures of personal assets and liabilities by holders of public office (World Bank 2001, 2017). Anti-corruption laws must be enforced through an independent judicial system based on the rule of law, but proper implementation and enforcement face challenges due to the scarcity of politicians with integrity and strong political will. Even rigorous laws can become ineffective. Equally important is a democratic culture based on rule of law that permits open public scrutiny and effective political opposition. A higher level of social capital also means that citizens are more likely to hold politicians accountable (Nannicini 2013 et al). They are more likely to punish politicians that pursue vested interests and appropriate economic rents for specific groups.

\subsection{Culture and institutions}

Culture and institutions interact and evolve in complex, non-linear, complementary ways, with mutual feedback effects and often unstable and unpredictable outcomes. As Hofstede (1984) indicated, they are endogenous variables largely determined by longer-term shifts in underlying drivers such as geography, technology, wars and other historical shocks. Both can determine economic choices and outcomes and it would be wrong to claim the causal superiority of either (Alesina \& Giuliano 2015). Thus, the same institutions (political and legal; regulatory; welfare state) may function differently in different cultures (trust; family

\footnotetext{
${ }^{4}$ From Viscount Bolingbroke (1740): "Casuistry...destroys distinctions and exceptions, all morality, and effaces the essential differences between right and wrong' (from Oxford English Dictionary online).
} 
ties; individualism; generalized morality; work-luck), but culture may evolve in differing ways depending upon types of institutions.

It is helpful in considering cultural and institutional change to distinguish between economic and political institutions (Acemoglu et al 2005). While political institutions distribute power across socio-economic groups this in turn determines the structure of economic institutions. Institutions denote which political pressure or interest group on a given issue has the power to control social choice. Thus, institutional change is the outcome of voluntary concessions by the controlling group under threat of fracturing the 'social contract'. An example of a controlling group is an 'elite network'.

\subsection{Elite networks}

Elite networks exist in every country (Moore 1979; Moore et al 1980). They may be overt or covert in their exercise of power. In countries where there is high power distance, their presence is more noticeable. To understand corruption in the Asia-Pacific region, addressing the underlying political culture requires understanding the elites of the region. Indeed, the economic forces in the region are driven by elites shaping the political culture and hampered by limits of civil society when the latter is allowed to exist and express.

In the region, elite networks are nominally found in politics, the private sector, the bureaucracy and in some cases, more overtly in the military sphere (dela Rama and Rowley 2017). There can be cross-overs such as when the military elites participate in the private sector. The prime example of this is China where its unitary political system has allowed the ease of transfer of princelings from military to politics and to business (Bickford 1994). Other countries where similar examples exist or have existed include East Timor, Myanmar, South Korea, Thailand and Vietnam (Andrews \& Htun 2017, McCargo 1998, Phuong 2017, Scambary 2017, Yoo \& Lee 2009). The power and privilege of access has allowed the 
politically-connected elites to reify their dominance and is reflected in the primacy of familyowned business groups in the region (Claessens et al 2000).

To answer our research question we conducted two desk surveys. First, to identify the relevant multilateral agreements, principles and working groups in place to address corruption and promote anti-corruption efforts in the region. Second, to compare and contrast the experiences of anti-corruption commissions around the region.

\section{Survey one: Anti-corruption frameworks applicable in the region}

The first survey looks at anti-corruption frameworks with a specific focus on the private sector role in corruption, both within the private sector and between the private and public sectors.

The UN Convention Against Corruption (UNCAC) (2005) is the 'only legally binding universal anti-corruption instrument' signed by 140 countries at the time of writing. In addition to bribery and corruption, the Convention's articles specifically also define trading in influence (Article 18), abuse of functions (Article 19) and other acts of private sector corruption such as laundering the proceeds of crime (Article 23).

The UN Global Compact (UNGC) (2004) is a voluntary initiative undertaken by the private sector to support universal sustainability principles and sustainable development goals of the UN. In particular, the $10^{\text {th }}$ Principle of the Compact directly addresses corrupt actions by private sector participants: 'Businesses should work against corruption in all its forms, including extortion and bribery.'

Private sector signatories to the Compact are expected to commit to this principle by actively avoiding and preventing corruption, and working with stakeholders. (UN Global Compact 2000) 
The OECD's Anti-Bribery Convention on Combating Bribery of Public Foreign Officials in International Business Transactions (2009) legally binds OECD member-states in criminalising the "bribery of foreign officials [and is] an anti-corruption instrument focused on the supply side of the bribery transaction.' Article 10 of the Convention sets out the conditions for extradition for those to have bribed foreign officials.

The OECD is also a partner with the G20 Anti-Corruption Working Group (G20-ACWG) (2010), which covers the 20 most economically advanced countries. The ACWG monitors the commitments made in the ratification of UNCAC as it recognises the 'significant negative impact of corruption, economic growth, trade and development. The G20 ACWG in 2015-16, looked at the problems of opacity in business ownership such as 'beneficial ownership transparency.

In 2008, the South East Asia Parties Against Corruption (SEA-PAC) was established to help ASEAN members (with the exception of Myanmar) 'to strengthen collaborative efforts against corruption [and] increase capacity and institutional building among the parties in preventing and combating corruption.'

Finally, the APEC Anti-Corruption and Transparency Working Group (2011) was established to institutionalize member-countries' work in order to address corruption's 'serious threat to sustainable economic growth, good governance, market integrity, and enhanced trade and investment.'

The frameworks mentioned above show the need for mutual cooperation and exchange of information when it comes to addressing corruption across countries and in the region. These frameworks do not sit in isolation. Civil society participation, such as Transparency International's (2017) work in the region helps inform the continued fight against corruption; 
while on the private sector side, the International Corporate Governance Network's (ICGN) guidance on anti-corruption practices (2015) helps its investor members avoid such practices.

Countries in the Asia-Pacific region are nominally signatories to these agreements and some are members of the aforementioned working groups with the work undertaken in these forums influencing the policy resolutions of their respective anti-corruption commissions.

These international anti-corruption instruments identify a broad range of interpretations of 'corruption' including 'grey areas' such as 'trading in influence', 'good governance' and 'market integrity' with a clear role articulated on the supply side of 'political corruption', namely the role of the private sector.

The next section looks at a select group of anti-corruption commissions around the region and how the individual experiences have been shaped by the specific demands and subjected to the issues of their national interests, culture and values.

\section{Survey two: Anti Corruption Commissions around the Asia-Pacific region}

This second survey shows the comparative findings and responsibilities of six anti-corruption bodies in five Asia-Pacific countries. These bodies are a product of their local conditions and culture and they continue to be shaped by balancing their varying experiences of corruption and dishonourable conduct against their individual values of integrity. The following table lists the name of the different bodies, their remit and private sector oversight.

[Insert Table 1 here]

\subsection{China's Central Commission for Discipline Inspection (CCDI)}

In a one-party state, China, the CCDI, is the sole organ to investigation malfeasance of Communist Party members and corruption in general. After high profile cases of corruption 
of party members, who have fallen out of favour such as Bo Xilai, a Minister of Commerce and the former party chief in Chongqing (Anderlini 2012, Guo 2014), President Xi Jinping led a high profile anti-corruption campaign with international reach, including princelings residing in Australia (Garnaut 2012). However, Guo pointed out these efforts by the CCDI can be 'highly politicized owing to concerns about upsetting the existing balance of the power structure [and the Party] is reluctant to move towards a depoliticized legal system for its high-ranking leaders' (2014: 621) which means the lack of an independent legal system (Winckler and Doyon 2017) will continue to be the Achilles heel in the institutional development of the country and its fight against corruption.

Furthermore, the remit of this body includes investigating Communist party members internationally but it has been somewhat hampered with the lack of extradition treaties in several countries. There are also suspicions of politicized motives (Garnaut 2012) such as when Communist party members are seen to exercise undue political influence in their host countries where they have commercial and residential interests.

\subsection{Hong Kong's Independent Commission Against Corruption (ICAC)}

The widely influential Hong Kong Independent Commission Against Corruption (ICAC) was established in 1974, long before the former British colony's handover to China. Out of all the anti-corruption bodies in this section, the HK ICAC has the most formalised investigation unit to address private sector corruption, reflecting the status of the island as a global financial centre in the region. It has also influenced the establishment of anti-corruption bodies in Australia. Below is an abridged version of its organizational chart showing how broad its Operations Department is and how it investigates corruption and the different divisions examining private sector malfeasance in its many forms, opportunities and motivations: 
[Insert Figure 1 here]

ICAC also has a corruption prevention department with an advisory service assigned to the main industries present in Hong Kong: building management, financial industries, tourism and trading and logistics (Hong Kong ICAC 2018a). ICAC also addresses private-to-private sector corruption (Argandoña 2003) with a Prevention of Bribery Ordinance (POBO) which is explicit on principal-agent (Eisenhardt 1989) conflicts and issues (Hong Kong ICAC 2018b).

It continues to be in the best interest of the island that it operates a highly transparent system, quid pro quo, penalises the rotten few and supports a private sector so the latter has confidence in the functions of her public institutions - both sectors, in turn, securing the island's future and financial sustainability.

\subsection{Indonesia's Corruption Eradication Commission}

In the wake of its long Suharto dictatorship, Indonesia's civil society embraced the freedom and promise of democracy - warts and all:

Eradicating corruption, collusion and nepotism was a demand the student protestors made in the uprising against President Suharto in 1998, in the midst of the Asian financial crisis. (Widojoko 2017: 254)

Established in 2002, the country's Corruption Eradication Commission or Komisi Pemberantasan Korupsi (KPK) pursued corrupt targets in the police, judiciary and government and has been 'remarkably effective in identifying corrupt patterns in Indonesia's political officials and bringing even high-ranking officials to justice.' (Mietzner and Misol 2012: 118) 
However, this success ensured that in the process, the KPK also acquired very powerful enemies. Indeed, at one point the KPK faced dissolution and its future became uncertain until Indonesia's civil society, through the use of social media, demonstrated their overwhelming support for the KPK (Widojoko 2017). While its future is secure at the time of writing, there is the possibility that Indonesia's oligarchical elite will turn on the very body that seeks to reduce its power while use of social networks have also brought its own discord (see Lim 2017).

\subsection{Malaysia's Anti-Corruption Commission (MACC)}

Malaysia's Anti-Corruption Commission (MACC) had several iterations since 1967 before its present form was codified in 2009 under the Malaysian Anti-Corruption Commission Act of 2009. Its role is to 'eradicate corruption, abuse of power and malpractice.'(MACC 2016) MACC is active on social media with a Twitter page @SPRMMalaysia and a mobile app to report corruption (MACC 2018).

In the last 30 years, there has been a plethora of Malaysian initiatives that have sought to tackle corruption but their effectiveness remained weak in the face of political corruption and a bureaucracy that reflects existing racial/ethnic policies. In Malaysia as in other countries, anti-corruption institutions cannot function as they stand, in the absence of political will and good governance and leadership (Siddiquee 2010: 169)

An example of this occurred in July 2018 when the former Malaysian Prime Minister, Najib Razak, was arrested for corruption offences (McKenzie 2018). Razak, his family and his associates engaged in money laundering involving the country's sovereign wealth fund (1Malaysia Development Berhad or 1MDB) amounting to over US billion dollars which caught the eye of the US Department of Justice's Kleptocracy Asset Recovery Initiative (2016, 2017) and the Australian Federal Police (Begley 2018). Razak's activities were the 
subject of a Wall Street Journal (Wright and Clark 2015) and an Australian Four Corners investigation (Besser 2016) showing the international reach of the former Prime Minister's ill-gotten gains. Arguably, the catalyst to his downfall was the personal donation of USD681M made by a member of the Saudi Royal Family into Razak's account (Holmes 2016).

The fallout from this scandal was the rejection by Malaysians of Razak's party in the 2018 elections and the re-election of former president Mahathir Mohammad who campaigned heavily on an anti-corruption platform. Under his tenure, Razak had previously tried to stymie any probe into his dealings by replacing the country's Attorney-General and shutting down a 2015 MACC investigation (Latiff 2018).

However, it remains to be seen whether there will be consistent intestinal fortitude to pursue acts of malfeasance that will finally break the culture of political corruption in the country. When a country's leaders engage in corruption, they have tacitly approved a culture of corruption to embed in its institutions.

\subsection{South Korea's Anti-Corruption and Civil Rights Commission}

South Korean's economic development from the miracle decades of the 1960s to 1980s saw a political-business nexus of crony capitalism that allowed the collusion of an 'uninterrupted inflow of extorted subordinates of the government from chaebol owners.' (Oh 2017: 243). As argued by Oh (2017), South Korean corruption has changed from state-led to chaebol-led. Chaebols, the business group conglomerates that rule the Korean private sector, are increasingly seen as a liability to further political democratisation in the country preventing the transformation of the country from a chaebol republic to a market democracy (Kalinowski 2016). 
The country's first anti-corruption commission was established in 2001. It was reorganised in 2005 and in 2008, in its current form, South Korea's Anti-Corruption and Civil Rights Commission (ACRC) was the result of the amalgamation of three existing public bodies in 2008: the Ombudsman of Korea, the Korean Independent Commission Against Corruption and the Administrative Appeals Commission (South Korea ACRC 2016a). The table below sets out the country's anti-corrupt institutional evolution:

[Insert Table 2 here]

Lee and Jung (2010) noted that the merger has resulted in a weaker institutional body. The ACRC's role and functions are heavily organised around public sector and civil complaints against different government bodies. They also include whistleblower protection and reporting of public subsidy fraud (South Korea ACRC 2016b). The supervision it has over private sector corruption is limited to how public officials interact with their private sector counterparts such as the enforcement of the Improper Solicitation and Graft Act (South Korea ACRC 2016c). In 2012, an ACRC survey reported at least $1 \%$ of citizens had paid bribes to public officials or entertained them in bars or other activities as a matter of respect or courtesy and to prompt business transactions (Kalinowski 2016).

It is beyond the oversight of the ACRC to investigate wider, grander corruption by chaebols as it does not have responsibility to cover elections when instances of political corruption through private sector donations occur.

\subsection{Thailand's National Anti-Corruption Commission}

Thailand's National Anti-Corruption Commission (NACC) was formally established in 2008 from previous iterations (Thailand NACC 2014a). The country's body of legislation addressing corrupt practices is extensive with 17 pieces of regulatory instruments (SEA-PAC 
2014). Its main mandate is to investigate public officials through an assets test especially if they have 'become unusually wealthy [emphasis added] or committed an offence of corruption, malfeasance in office or malfeasance in judicial office.' (Thailand NACC 2014b) The NACC has investigated the country's former Prime Minister Yingluck Shinawatra over her family's business interests and a rice subsidy government program (McKirdy et al 2017) for which she was subsequently sentenced to jail in absentia (Cochrane 2017). She follows in the footsteps of her brother, another former PM, Thaksin Shinawatra, who was the subject of a previous NACC investigation a decade earlier and was also jailed in absentia (Biswas et al 2015). At the time of writing, both Shinawatra family members are still in exile and there is

criticism of other Thai "elite groups [using] the mantra of "corruption"” (Dyussenov 2017: 337) as a vendetta against the Shinawatras, politicising the NACC in the process.

These six case studies show the spectrum of successful and not-so-successful pursuit of corrupt actors. Nevertheless, these anti-corruption bodies provide an avenue for public assurance in their institutions despite their imperfections. Within the region, anti-corruption commissions are important institutions to help and improve each nation's development by confronting deeply embedded political culture and associated elites.

\section{Australian political culture and Australian political institutions}

In considering Australia's journey as it looks to establishing its own national anti-corruption watchdog, it is necessary to provide a context of Australian political culture and its institutions in order to understand the state of the country's NIE. In particular, there is the overarching and long-standing concept of 'mateship' where - in its most dysfunctional form it can border on 'crony culture' (Cave \& Kwai 2018) facilitated by favours of rent-seeking and regulatory capture involving the Australian elite networks in business and political spheres (Murray \& Frijters 2017). 
In more recent decades of broad political consensus on market-driven reform agendas in Australia, corruption has become particularly manifest at the intersection of issues such as privatization, marketization, outsourcing, competition, lobbying, think tanks, industry bodies and other elements that are also to varying degrees present in other OECD countries. Corruption arises particularly in those sectors of the economy with significant potential for 'rent seeking' by preferentially influencing government policies, subsidies, funding programs, regulations and outsourcing, that favour rich, established interests. These sectors include minerals, energy and resources; aged care and private health care; banking, finance and consulting; telecommunications, media and technology; infrastructure, construction and property development; amongst others. The range of such specific political culture issues addressed within this paper demonstrates the breadth of remit and powers with which an effective federal anti-corruption watchdog would need to operate.

The representative voice of the community is expressed through Australian public and political institutions bearing on integrity and anti-corruption. The key integrity and anticorruption institutions that give voice to the Australian community's values and concerns include the Auditor-General, Electoral Commission, Ombudsman, Royal Commissions, Regulators, Judiciary, the Police, and the Legislature. Concerns may also be raised through the Media, NGOs and Whistleblower associations. Underpinning this is the 'rule of law' through a strong presence and inheritance of English Common Law. The ethical behaviour of politicians and public servants is governed generally through non-statutory voluntary 'codes of conduct'. The design of an anti-corruption federal body in respect to powers and scope will need to reflect the existing institutions' mandates, experiences, strengths and weaknesses.

\subsection{The proposed National Integrity Commission}


While there are state-based anti-corruption bodies, at the time of writing one does not exist at the federal level. In Australia's federal system, moves towards a National Integrity Commission were most recently informed by an inquiry held in 2016-17. While the relevance of state anti-corruption bodies, once established, has not been questioned - their powers are under scrutiny: too powerful in the case of NSW, not powerful enough in Tasmania. Some of them exhibit the ongoing stresses and strains of the push (such as cases of corruption reported in the media and ensuing widespread public opprobrium) and pull (such as powerful elite networks) factors that underpin their continued existence.

Nevertheless, their track record is evidence of their importance and critical role in ensuring accountability in the functioning and the transparent discharge of the duties of state governments, state bodies and public servants. However, the extent of their powers remain a contested issue - they have too much power from the point of view of those being scrutinised, too little from those who wish to hold power to account. In particular, their often secret investigatory and associated public hearing procedures see them tarred by their opponents as 'kangaroo courts'.

Federal parliamentarians, and indeed sections of Australian business, have long resisted and indeed denied the need for such a body at the national level (Oquist 2018) despite longstanding public support for its establishment and continuing decline in public trust of politicians (Denniss 2017). Federal politicians are clearly unenthusiastic about taking the risk of scrutinising their own actions. In February 2018, the then former deputy Prime Minister Barnaby Joyce resigned from his position due to personal issues which exposed his business 'mates' (Cave and Kwai 2018; McIlroy 2018), while in April 2018 the then Prime Minister Malcolm Turnbull awarded a half-a-billion dollar untendered grant to the Great Barrier Reef Foundation whose board members represented some of the highest polluting companies and industries in the country (Cox 2018). 
The Joyce Affair and Reefgate, the sobriquets given to these incidents, showed the underbelly of Australia's federal political class - the intertwining of personal affairs, lobbying, ministerial discretion and the value of political connections at the expense of transparency and the public interest.

While cases such as Joyce tend to gain the public's attention and opprobrium over misbehaving taxpayer-funded public figures, it is in the actions of the less sensational, breadand-butter personalities in charge of Australia's federal agencies that also support the case for a federal anti-corruption watchdog as a missing, crucial piece in Australia's institutional integrity jigsaw.

In 2017, the main revenue generating arms of the federal government, the Australian Tax Office (ATO) and Australian Customs, had incidences of corruption by senior public servants that underlined the ineffectiveness of existing bodies to tackle malfeasance. In May 2017, the ATO's Deputy Commissioner, Michael Cranston, was forced to resign after it was uncovered he was connected, through a relative, to a syndicate that perpetrated a AU\$165 million tax fraud (Olding \& Levy 2017). In August 2017, an Australian Border Force officer and former customs officer were arrested over importation of illegal drugs (Hall 2017) amidst allegations of links to criminal families and transnational crime, and with this incident the systemic failure of an internal anti-corruption watchdog to gain hold within the agency (McKenzie \& Baker 2017).

It was in this climate of growing public mistrust that the inquiry into establishing a federal anti-corruption watchdog was set in motion. As a former Victorian Supreme Court judge Stephen Charles said: 
It is already well known that there is abundant corruption in the other capital cities around Australia, why on earth does the air suddenly clear around Queanbeyan [near the capital Canberra]? (in Peacock 2017)

In January 2018, the Federal opposition Labor leader Bill Shorten announced his support for establishing a Federal anti-corruption body, a month after the resignation of a Labor senator found to be unduly influenced by Chinese donors (Walker 2017). Chinese interference in Australian politics is largely based through political donations of significant sums to both sides of politics (Murphy 2017). The community interest lies in whether such donations interferes with differing foreign policies over the South China Sea (see Lester \& dela Rama 2018) and adversely influences domestic policies covering the treatment of pro-democracy activists in Australia.

In support of this proposed body, Shorten (2018) stated it will be 'modelled on the lessons of the state anti-corruption bodies' with its powers wide-ranging and well-resourced analogous to a 'standing Royal Commission.' The success of the Banking Royal Commission (2018), which shone light on malfeasance in the financial services sector, also reinforced this need.

Amidst political instability afflicting the sitting government, in November 2018, the Australian independent politician, Cathy McGowan, introduced a national integrity commission bill (McGowan 2018) based on consultation with a wide variety of anticorruption stakeholders including Transparency International Australia. Her bill proposed three integrity commissioners covering national integrity enforcement, law enforcement and whistleblower protection. In December 2018 the minority Morrison Government announced a Commonwealth Integrity Commission, which proposed two integrity divisions: law enforcement and public sector integrity (AG 2018). However, it has been roundly criticised as a 'very weak' model with no public hearings, no public findings and direct referral to the 
prosecutor for decision whether to act or not in the public sector integrity division (Fitzsimons 2018) which could leave politicians and their associates unaccountable publicly.

It is expected that Australia will have some form of national integrity commission after the next federal election in 2019 , with the likely structure a negotiated outcome from the above three proposals. Central to its potential effectiveness in the 'public interest' will be its independence and transparency in conducting public hearings with public findings.

\section{Discussion: Institutions, corruption and implications for the region}

"...[I]t is not by the consolidation, or concentration of powers, but by their distribution, that good government is effected."-Thomas Jefferson (1821 in Ford 1904-05)

“...[N] o one ever seizes power with the intention of relinquishing it." - 1984 (George

$$
\text { Orwell) }
$$

The problem of corruption is linked to the notion of integrity (Sampford 2016). Corruption is the misuse of public position for private gain. Integrity is the appropriate use of public power for public ends. The latter sets the standard and associated process while the former is a deviation from that standard and practice. In a democracy it is for the community to set the expected standards of integrity against which corruption can be determined. In a representative democracy, the community devolves its standard setting to its parliamentary representatives on the assumption that they will act in the public interest. The moral and ethical problem of corruption arises when the political process among politicians and governments expressed in legislation becomes perverted by undue private influence of vested interests over public policy-making and decision-making.

The chart below places all of these issues in an Australian NIE:

[Insert Chart 2 here] 
While the detail in this chart can be rather complex, the ecosystem - by its nature - is complex, malleable and changeable. The notion of the 'public good' is the desired outcome, balanced but shaped by the forces of institutions, culture, trust and values. Broader, often internationally originating drivers such as globalisation, privatization, neo-liberalism and increasing corporatisation have been perceived as resulting greater inequality in the country. Homo economicus, and its dominant self-interest, is at odds with the homo reciprocans of public institutions. Increasing private sector power, for example, through legitimate 'tax avoidance' schemes have resulted in community concerns that they are not paying their 'fair share' of social expenses in operating in a democratically stable country (Clark 2017). While Australia provides a secure legal environment for property rights; the institutional costs (Chang 2005) in supporting such an environment is increasingly being ignored by that sector.

The private sector has an instrumental role to play in a country that prides itself to be liberally democratic. It is in the best interests of the sector that businesses support the public institutions that balance their needs with that of the community. Where corrupt players participate in a sector, the private sector participants that do not engage in this are unfairly penalised. A strong private sector benefits from an even playing field, with government institutions acting and exercising their roles of impartial referees. Where these same institutions are captured by vested interests, then the sector and by default, the community loses. Public institutions are the fine line that distinguishes functional stable and equitable societies from dysfunctional ones.

The proposed framework in this paper maps the field where institutions and corruption interplay. It can be adapted and applied to any country in the region. Identifying how the relevant cultural variables are embedded within a given society and where they lie in the integrity-corruption spectrum illuminates understanding of how institutions operate in corrupt environments and cultures to both thwart and counter broader corruption. 
In Australia, political corruption is generally not perceived as a major problem disrupting the entire government polity as it does in other countries in the Asia-Pacific region. However, its standing in global corruption indices has decreased notably over the past six years, to stand at $13^{\text {th }}$ least corrupt country in 2018 shadowing an embedded and growing problem in this area:

The misuse of travel allowances, inadequate regulation of foreign political donations, conflicts of interest in planning approvals, revolving doors and a culture of mateship, inappropriate industry lobbying in large-scale projects such as mining, and the misuse of power by leading politicians have no doubt had an impact. (Ryan 2018)

There is a also a decline in public trust including a good deal of concern about how fairly people are treated by public officials and about the lack of government responsiveness and sense of powerlessness in their access to, and influence in, the political process (Bean 2012).

Public perceptions of the probity with which politicians act are useful indicators of political integrity and thereby sustaining the trust of citizens in their politicians. These public perceptions of probity are 'coherent, substantively meaningful, responsive and most importantly, they do matter' (Rose 2014). Probity is seen to be about 'playing by the rules' or in the 'spirit of the public service'. It is less about formal, prescriptive rules, and more by way of an appropriate exercise of public office. The process of governing is emphasized over the outcomes produced by government.

Machiavelli posed a rift between a morally admirable and a virtuous political life. An ethical challenge lies in the art of compromise without losing integrity but this poses a basic political dilemma: democratic politics is accepted as the art of political compromise, 'the art of the possible', yet as a society we appear to be allergic to it when it happens. Can such moralistic assumptions legitimately justify the contemporary vilification and loss of trust in politicians? 
'A compromising disposition' is an ambiguous virtue, politically expedient but not necessarily morally admirable; and while uncongenial to moral integrity it is an essential aspect of political integrity (Tillyris 2017). To argue that political integrity should be akin to moral integrity idealises the notion of political integrity and the day-to-day, practical and messy context within which democratic politicians operate. This real world context is characterized by a plurality of incompatible traditions, each with its own values and principles.

In this view, what matters for integrity is how decisions are made and how policies are implemented (Rothstein 2011). This suggests that a dictatorship producing outcomes desired by voters would be regarded as having less political legitimacy and perceptions of trustworthiness than those produced by a democratic system of government. This conclusion is bolstered by the evidence that despite decreasingly low levels of trust in the political system, most citizens (Norris 2011) still consider democracy the best form of government. But it must be recognized that this is a fragile consensus currently under real threat from the rise of authoritarian, nationalistic politics and politicians.

Issues of policy access and influence in return for political donations and post-public office employment as lobbyists or consultants, as well as the influence of privately funded policy think tanks and corporate lobbyists, are growing in importance and particularly hard to grapple with for transparency, accountability and integrity. As former Senator Faulkner (2012) pointed out:

The perception of undue influence can be as damaging to democracy as undue influence itself. It undermines confidence in our processes of government, making it difficult to untangle the motivation behind policy decisions. 
The 'fluid dynamics' of political culture means that it can paradoxically both inhibit political change and be a source of it (Welch 2013). Paradoxically too, it can serve policy-makers well despite its poor scientific standing. It may not explain social conduct, but it can be used to devise intelligent questions about the likely consequences of political actions. The notion of political culture poses an apparent contradiction in both the fluidity and the inertia of political life: between the unacceptable extremes of complete environmental or complete cultural determinism. The central liberal truth is 'that politics can change culture and save it from itself'. The problem is one of explanatory circularity: to effect cultural change it needs already to have happened. Culture enters as an explanation for both the success and the failure of programs of cultural change.

In establishing a NIE, a wider anti-corruption institutional infrastructure needs to be recognised and further developed. According to Pope (2000), an NIE involves a number of 'pillars' The 'pillars' (Greek temples) include the legislature, executive, judiciary, auditor general, ombudsman, watchdog agencies, public service, media, civil society, private sector and international actors. While these institutional pillars may vary across the region, the common thread unifying these are that these players are underpinned by cross-cutting public awareness and society's values.

The NIE can be likened to a 'bird's nest', built up over time from material to hand, with components individually weak but in combination effective. These individual elements dynamically and constantly interacting with each other, pulling first one way then the other, constantly re-configuring the balance of interests, private and public. This is the essential complex dynamic of a systemic failure in politics and government. While some elites would wish to have less accountability and engage in rent-seeking; short-term myopic self-interest has a long-term debilitating effect. This is the test that confronts the institutional quandary of establishing a federal ICAC in Australia, and as earlier mentioned in this paper, is akin to 
issues confronting other countries in the region. Striking an appropriate balance between public interest, private gain and community good is necessarily the ongoing result of a negotiated outcome reflected in the operationalization of anti-corruption commissions around the region. Further research, such as ethnographic approaches, may enhance this framework so as to increase its relevance and its adoptability in other countries of the region. It would provide further insights for those countries into the nature of the inevitable complex systemic struggle to establish an effective ant-corruption institution. It might also act as a framework against which those countries that have already put in place their anti-corruption commissions - as a national institution - might review their ongoing effectiveness and viability. The NIE model is but a start in defining the boundaries of the field of corrupt practices on an institutional level and the values that underpin such activities.

\section{Conclusion}

This paper started by considering the different experiences of anti-corruption commissions around the Asia Pacific region set against the current debate in Australia of establishing a national anti-corruption commission. It proposes a framework that we term 'national integrity ecosystem' to provide a greater understanding of where and how a national integrity system can be placed in its attempt to address corruption and promote anti-corrupt practices effectively and systemically. It also sought to compare the experience of corruption and its effects with anti-corruption commissions of the Asia-Pacific region. We use these cases to discuss Australia's attempts to date to create a national body to deal with federal level corruption issues. This paper shows that while there are international frameworks, agreements and principles in place in the region and globally to deal with corrupt behaviour and promote anti-corrupt practices, the local cultural and institutional context of a country is paramount. Anti-corrupt practices must adapt and address the local issues and political culture efficiently and effectively in order to prevent further political behaviour that is 
corrosive of public trust. This is critical to rebuilding trust in our political institutions as reflecting community values and the NIE framework provides an insight into the possible management of corruption across the Asia-Pacific.

\section{References}

G20 ACWG (2010) G20 Anti-Corruption Working Group Anti-Corruption Action Plan https://star.worldbank.org/star/sites/star/files/g20_2015-2016_anticorruption_action_plan_australia_2014.pdf

Acemoglu, D., Johnson, S., \& Robinson, J. A. (2005). Institutions as a fundamental cause of long-run growth, Chapter 6, pp.385-472 in Aghion, P. \& Durlauf, S. (eds) Handbook of Economic Growth, Amsterdam: Elsevier

Acemoglu, D. \& Robinson, J.A. (2012) Why Nations Fail: The Origins of Power, Prosperity and Poverty, New York: Crown Publishing Group

AG (2018) Attorney-General of Australia: Commonwealth Integrity Commission consultation paper https://www.ag.gov.au/Consultations/Documents/commonwealthintegrity-commission/cic-consultation-paper.pdf

Alesina, A., \& Giuliano, P. (2015) Culture and institutions, Journal of Economic Literature, 53(4), 898-944

Allan, J. (2014) Democracy in decline: Steps in the wrong direction, Montreal: McGillQueen's University Press

Almond, G. A. (1956) Comparative political systems, The Journal of Politics, 18(3): 391-409

Almond, G. A. (1963) Political systems and political change, American Behavioral Scientist, 6(10): 3-10

Anderlini, J. (2012) Bo Xilai: power, death and politics, Financial Times, $21^{\text {st }}$ July https://www.ft.com/content/d67b90f0-d140-11e1-8957-00144feabdc0

Andrews, T. G. \& Htun, K.T. (2017) Chapter 15: Corruption in Myanmar: insights from business and education, pp. 233-241 in dela Rama \& Rowley (2017) The Changing Face of Corruption in the Asia Pacific: Current Perspectives and Future Challenges, Amsterdam: Elsevier

APEC (2011) Anti-Corruption and Transparency Working Group https://www.apec.org/Groups/SOM-Steering-Committee-on-Economic-and-TechnicalCooperation/Working-Groups/Anti-Corruption-and-Transparency

Argandoña, A. (2003) Private-to-private corruption, Journal of Business Ethics, 47 (3): 253267

Banking Royal Commission (2018) Royal Commission into Misconduct into the Banking, Superannuation and Financial Services Industry https://financialservices.royalcommission.gov.au/Pages/default.aspx 
Bean, C. (1993) Public attitudes on the monarchy-republic issue, Politics, 28(4): 190-206

Bean, C. (2012) Are we keeping the bastards honest? Perceptions of corruption, integrity and influence on politics, Chapter 7, pp.94-106, in Pietsch, J. \& Aarons, H. (eds) Australia: Identity, Fear and Governance in the $21^{\text {st }}$ Century, Canberra: ANU Press

Begley, P. (2018) Malaysian top cop has \$320k seized by AFP, doesn’t want it back, Sydney Morning Herald, $2^{\text {nd }}$ March https://www.smh.com.au/national/nsw/malaysian-top-cop-has$\underline{\text { 320k-seized-by-afp-doesn-t-want-it-back-20180301-p4z2dw.html }}$

Benabou, R. (2008) Ideology, Journal of the European Economic Association, 6(2-3), 321352.

Besser, L., (2016) State of Fear, 4 Corners, $28^{\text {th }}$ March http://www.abc.net.au/4corners/stateof-fear-promo/7275348

Bickford, T.J. (1994) The Chinese Military and its Business Operations: The PLA as Entrepreneur, Asian Survey, 34 (5): 460-474.

Biswas, A.K., Kastner, M.K. \& Tortajada, C. (2015) The Rice and Fall of Yingluck Shinawatra, The Diplomat, $21^{\text {st }}$ May https://thediplomat.com/2015/05/the-rice-and-fall-ofyingluck-shinawatra/

Bove, A. (2002) The Limits of Political Culture: An Introduction to G.W.F. Hegel's Notion of Bildung. In Questionable Returns, ed. A. Bove, Vienna: IWM Junior Visiting Fellows Conferences, Vol. 12. http://www.iwm.at/wp-content/uploads/jc-12-06.pdf

Bratsis, P. (2014) Political corruption in the age of transnational capitalism, Historical Materialism, 22 (1): 105-128

Cave, D. \& Kwai, I. (2018) Politician's affair puts spotlight on Australia's crony culture, New York Times, $14^{\text {th }}$ February https://www.nytimes.com/2018/02/14/world/australia/barnabyjoyce-affair.html

Chang, H-J. (2005) Understanding the Relationship between Institutions and Economic Development - Some Key Theoretical Issues, Paper presented at the WIDER Jubilee Conference, 17-18 June, Wider: Helsinki.

Chin, K.-1. (1999) Smuggled Chinese: clandestine immigration to the United States, Philadelphia: Temple University Press

Clark, E. (2017) The ATO just dropped corporate tax data and more than 700 companies paid nothing, $A B C$ News, $7^{\text {th }}$ December http://www.abc.net.au/news/2017-12-07/corporate-taxdata-released-by-ato/9236878

Cochrane, L. (2017) Thai ex-PM Yingluck Shinawatra found guilty over rice subsidy policy, $A B C$ News, $27^{\text {th }}$ September http://www.abc.net.au/news/2017-09-27/ex-thai-prime-ministeryingluck-sentenced-to-five-years/8992908

Collignon, P., Beggs, J.J., Walsh, T.R. Gandra, S. \& Laxminarayan, R. (2018)

Anthropological and socioeconomic factors contributing global antimicrobial resistance: a univariate and multivariate analysis, The Lancet: Planetary Health, 2 (9): 398-405 
Cox, L. (2018) 'Due diligence' on \$444M Great Barrier Reef grant was for separate project, The Guardian Australia, $13^{\text {th }}$ August https://www.theguardian.com/australianews/2018/aug/13/great-barrier-reef-foundation-not-aware-of-due-diligence-for-444m-grant

Dacin, M.T., Goodstein, J., \& Scott, W.R. (2002) Institutional Theory and Institutional Change: Introduction to the Special Research Forum, Academy of Management Journal, 45 (1): $45-57$

dela Rama M. (2011) Corporate Governance Reforms in the Philippines: An Ethnographic Approach, PhD Thesis, University of Technology Sydney.

dela Rama, M. (2017) Chapter 7: Corruption, corporate governance and building institutions in the Asia-Pacific pp.93-108, in dela Rama \& Rowley (2017) The Changing Face of Corruption in the Asia Pacific: Current Perspectives and Future Challenges, Amsterdam: Elsevier

dela Rama, M. \& Rowley (2017) The Changing Face of Corruption in the Asia Pacific: Current Perspectives and Future Challenges, Amsterdam: Elsevier

Denniss, R. (2017) Canberra needs a watchdog, The Monthly, September https://www.themonthly.com.au/issue/2017/september/1504188000/richarddenniss/canberra-needs-watchdog

Dine, J. (2017) Chapter 6: It takes two people to tango (or more!): the corrupt and debased culture of neoliberalism, pp.81-92 in dela Rama, M. \& Rowley, C. (eds) The Changing Face of Corruption in the Asia-Pacific: Current Perspectives and Future Challenges, Amsterdam: Elsevier

Dyussenov, M. (2017) Who sets the agenda in Thailand? Identifying key actors in Thai corruption policy, Journal of Asian Public Policy, 10 (3): 334-364

Eisenhardt, K.M. (1989) Agency Theory: An Assessment and Review, Academy of Management Review, 14 (1): 57-74

Faulkner, J. (2012) Political integrity: Faulkner's full speech, Sydney Morning Herald, $5^{\text {th }}$ December https://www.smh.com.au/politics/federal/political-integrity-faulkners-full-speech20121204-2at2d.html

Fitzsimons, P. (2018) The expert you pick for a corruption body without bite, Sydney Morning Herald, $23^{\text {rd }}$ December https://www.smh.com.au/national/the-expert-you-pick-for-acorruption-body-without-bite-20181221-p50noa.html

Ford, P.L. (ed) (1904-05) The Works of Thomas Jefferson, New York and London: GP Putnam's and Sons

Garnaut, J. (2012) Princelings and paupers, Sydney Morning Herald, 26 ${ }^{\text {th }}$ May, http://www.smh.com.au/world/princelings-and-paupers-20120525-1za5n.html

Guo, X. (2014) Controlling Corruption in the Party: China's Central Discipline Inspection Commission, The China Quarterly, September, 219: 597-624 
Guth, A.P. (2010) Human trafficking in the Philippines: the need for an effective anticorruption program, Trends in Organized Crime, 13 (2/3): 147-166

Hall, E. (2018) Integrity in democratic politics, British Journal of Politics and International Relations, 20 (2): 395-408

Hall, L. (2017) Police swoop on alleged corruption inside Australian Border Force, $A B C$ News, $10^{\text {th }}$ August http://www.abc.net.au/news/2017-08-10/police-bust-alleged-border-forcesmuggling-ring/8793626

Hofstede, G. (1984) Culture's Consequences: International Differences in Work-Related Values, Abridged Edition, SAGE: London

Holmes, O. (2016) Saudi Arabia says money sent to Malaysian PM was a 'genuine donation', The Guardian, $15^{\text {th }}$ April https://www.theguardian.com/world/2016/apr/15/saudi-arabiamoney-malaysian-pm-najib-genuine-donation

Hong Kong ICAC (2017) ICAC's Institutional Strength https://www.icac.org.hk/en/intlpersp/control/institutional-strength/index.html

Hong Kong ICAC (2018a) Corruption Prevention Department https://www.icac.org.hk/en/cpd/struct/index.html

Hong Kong ICAC (2018b) Prevention of Bribery Ordinance https://www.icac.org.hk/en/law/law/pobopri/index.html

Hutchcroft, P.D. (1998) Booty capitalism: the politics of banking in the Philippines. Ithaca NY: Cornell University Press

ICGN (2015) Guidance on Anti-Corruption Practices https://www.icgn.org/sites/default/files/ICGN_Anti-Corruption_2015_0.pdf

Kalinowski, T. (2016) Trends and mechanisms of corruption in South Korea, The Pacific Review, 29 (4): 625-645

Lanchester, J. (2018) Can economists and humanists ever be friends? The New Yorker, 23 July https://www.newyorker.com/magazine/2018/07/23/can-economists-and-humanists-everbe-friends

Latiff, R. (2018) Malaysia's embattled Najib questioned by anti-corruption agency, Reuters, $22^{\text {nd }}$ May https://www.reuters.com/article/us-malaysia-politics-najib/malaysias-embattlednajib-questioned-by-anti-corruption-agency-idUSKCN1IN06O

Lee, K.-Y. (2000) From Third World to First: The Singapore Story (1965-2000) - Singapore and the Asian Economic Boom, New York: Harper Collins Publishers.

Lee, S.Y. \& Jung, K. (2010) Chapter 19: Public Service Ethics and Anticorruption Efforts in South Korea, in Berman, E.M., Moon, EJ. \& Choi, H. (eds) Public Administration in East Asia: Mainland China, Japan, South Korea and Taiwan, London: Routledge

Lester, M. \& dela Rama, M. (2018) Chapter 5: Neo-Protectionism in the Age of Brexit and Trump - what to do with powerful friends? Views from Australia, in Oberoi, R. \& Halsall, J. (eds) (2018) Revisiting Globalization: From a Borderless to a Gated Globe, Berlin: Springer 
Lim, M. (2017) Freedom to hate: social media, algorithmic enclaves, and the rise of tribal nationalism in Indonesia, Critical Asian Studies, 49 (3): 411-427

Ma, D. \& Yang, F. (2014) Authoritarian orientations and political trust in East Asian societies, East Asia, 31: 323-341

MACC (2016) Malaysian Anti-Corruption Commission - General Enquiry: Frequently Answered Questions http://www.sprm.gov.my/index.php/en/general-enquiry

MACC (2018) MACCMobile

https://itunes.apple.com/us/app/maccmobile/id1090338943\#?platform=iphone

Mackey, T.K., Kohler, J.C., Savedoff, W.C., Vogl, F., Lewis, M., Sale, J., Michaud, J. \& Vian, T. (2016) The disease of corruption: views on how to fight corruption to advance $21^{\text {st }}$ century global health goals, BMC Medicine, 14: 149-165

McCargo, D. (1998) Chapter 6 Elite governance: business, bureaucrats and the military, pp. 126-149 in Maidment, R., Goldblatt, D. \& Mitchell, J. (eds) Governance in the Asia Pacific, London: Routledge.

McGowan, C. (2018) National Integrity Commission bill http://www.cathymcgowan.com.au/national_integrity_commission_bill_2018

McKenzie, N. \& Baker, R. (2017) Sydney crime arrests: the inside story of corruption in the Australian Border Force, Sydney Morning Herald, $10^{\text {th }}$ August http://www.smh.com.au/national/sydney-crime-arrests-the-inside-story-of-corruption-inaustralian-border-force-20170809-gxsuka.html

McIlroy, T. (2018) Gina Rinehart's son John Hancock calls to Barnaby Joyce to resign, Australian Financial Review, $14^{\text {th }}$ February http://www.afr.com/news/gina-rineharts-sonjohn-hancock-calls-for-barnaby-joyce-to-resign-20180214-h0w29f

McKirdy, E., Olarn, K. \& Ly, E. (2017) Former Thai PM Yingluck Shinawatra has 'fled country' ahead of trial verdict, $C N N, 25^{\text {th }}$ August, https://edition.cnn.com/2017/08/24/asia/yingluck-shinawatra-trial-verdict/index.html

Mietzner, M. \& Misol, L. (2013) Military Businesses in Post-Suharto Indonesia: Decline, Reform and Persistence, Chapter 5, pp. 101-120 in Rüland, J., Manea, M.-G. and Born, H. (eds) The Politics of Military Reform: Experiences from Indonesia and Nigeria, Berlin: Springer

Mishler, W. \& Rose, R. (2001) What are the origins of political trust? Comparative Political Studies, 34 (1): 30-62

Moore, G. (1979) The structure of a national elite network, American Sociological Review, 44 (5): 673-692)

Moore, G., Higley, J., Deacon, D. \& Carrick, D. (1980) National elite networks in the United States and Australia, Journal of Sociology, 16 (1): 14-23

Murphy, K. (2017) Ban on foreign political donations open to challenge, legal experts say, The Guardian, $7^{\text {th }}$ December https://www.theguardian.com/australia-news/2017/dec/07/banon-foreign-political-donations-open-to-challenge-say-legal-experts 
Murray, C. \& Frijters, P. (2017) Game of Mates: How favours bleed the nation, E-book https://gameofmates.com

Nannicini, T., Stella, A., Tabellini, G. \& Troiano, U. (2013) Social capital and political accountability, Economic Policy, 5 (2): 222-250

Norris, P. (2011) Democratic Deficit, Cambridge: Cambridge University Press

North, D. (1991) Institutions, Journal of Economic Perspectives, 5 (1): 97-112

Nye, J.S. (1967) Corruption and political development: A cost-benefit analysis, American Political Science Review, 61 (2): 417-427

OECD (2009) Anti-Bribery Convention on Combating Bribery of Public Foreign Officials in International Business Transactions http://www.oecd.org/daf/anti-

bribery/oecdantibriberyconvention.htm

Oh, I. (2017) Chapter 16: From credible threats to credible commitments? The changing face of South Korean corruption, pp.243-251 in dela Rama \& Rowley (2017) The Changing Face of Corruption in the Asia Pacific: Current Perspectives and Future Challenges, Amsterdam: Elsevier

Olding, R. \& Levy, M. (2017) ATO Deputy Commissioner Michael Cranston to be charged over tax fraud, Sydney Morning Herald, $18^{\text {th }}$ May http://www.smh.com.au/national/atodeputy-commissioner-michael-cranston-to-be-charged-over-tax-fraud-20170517gw7gf2.html

Oquist, B. (2018) Why isn't business demanding an anti-corruption body? It would help Australia's economy, The Guardian, $13^{\text {th }}$ January https://www.theguardian.com/commentisfree/2018/jan/13/why-isnt-business-demanding-ananti-corruption-body-it-would-help-australias-economy

Orwell, G. (1949) 1984, London: Secker \& Warburg

Parsons, T. (1971). The system of modern societies. New York: Prentice Hall

Peacock, M. (2017) Federal ICAC: former judges call for national anti-corruption watchdog, ABC News 7:30 Report, $3^{\text {rd }}$ November http://www.abc.net.au/news/2017-11-02/formerjudges-call-for-federal-icac/9112396

Phuong, N.T. (2017) Chapter 14: Corruption in Vietnam: the current situation and proposed solutions, pp.221-232 in dela Rama \& Rowley (2017) The Changing Face of Corruption in the Asia Pacific: Current Perspectives and Future Challenges, Amsterdam: Elsevier

Pope, J. (2000) Confronting corruption: the elements of a national integrity system, Berlin: Transparency International

Proctor, A. (2017) Chapter 22: Petty Corruption in developing countries: here for the long term, pp.327-333 in dela Rama \& Rowley (2017) The Changing Face of Corruption in the Asia Pacific: Current Perspectives and Future Challenges, Amsterdam: Elsevier

Reisinger, W. M., Miller, A. H., \& Hesli, V. L. (1995) Public behavior and political change in post-Soviet states, The Journal of Politics, 57(4), 941-970 
Rogow, A.A \& Laswell, H.D. (1970) Political Corruption: Readings in Comparative Analysis, New York: Holt, Rinehart and Winston

Rose, J. (2014) The Public Understanding of Political Integrity: The Case for Probity Perceptions, London: Palgrave-Macmillan

Rothstein, B. (2011) The Quality of Government: Corruption, Social Trust and Inequality in International Perspective, Chicago: University of Chicago Press

Ryan, P. (2018) Australia slips in corruption index, ranks as $13^{\text {th }}$ least-corruption nation, $A B C$ News, $22^{\text {nd }}$ February https://www.abc.net.au/news/2018-02-22/australia-slips-in-globalcorruption-rank/9472114

Sampford, C. (2016) Submission 28: Establishment of a National Integrity Commission Select Committee, Senate Committee, Commonwealth of Australia https://www.aph.gov.au/Parliamentary_Business/Committees/Senate/Establishment_of_a_Na tional_Integrity_Commission/NIC/Submissions

Scambary, J. (2017) Chapter 18 The road to nowhere: the rise of a neo-patrimonialist state in East Timor, pp.267-277 in in dela Rama \& Rowley (2017) The Changing Face of Corruption in the Asia Pacific: Current Perspectives and Future Challenges, Amsterdam: Elsevier

Schneider, F. (2011) (ed) Handbook on the Shadow Economy, London: Edward Elgar

Scott, W.R. (1987) The adolescence of institutional theory, Administrative Science Quarterly, 32: 493-511

SEA-PAC (2008) South East Asia Parties Against Corruption Objectives http://www.seapac.org/?page_id=4225

SEA-PAC (2014) Legislation http://www.sea-pac.org/?page_id=70

Selznick, P. (1957) Leadership in Administration, New York: Harper \& Row

Shi, T. (2001) Cultural values and political trust, Comparative Politics, 34 (4): 401-419

Shorten, B. (2018) Address to the National Press Club, 30 ${ }^{\text {th }}$ January

http://www.billshorten.com.au/address_to the national_press_club_tuesday_30_january_201 $\underline{8}$

Singleton, G., Aitkin, D., Jinks, B. \& Warhurst, J. (2014) Australian Political Institutions, $10^{\text {th }}$ Edition, Frenchs Forest NSW: Pearson Australia.

Siddiquee, N.A. (2010) Combating corruption and managing integrity in Malaysia: A critical overview of recent strategies and initiatives, Public Organization Review, 10: 153-171

Smelser, N.J. \& Swedberg, R. (2005) (eds) The Handbook of Economic Sociology, $2^{\text {nd }}$ edition, New Jersey: Princeton University Press

Smith, A. (1776) Wealth of Nations, London: Strahan and Cadell

Smith, R. (2001) Australian Political Culture, Frenchs Forest NSW: Pearson Education 
South Korea ACRC (2016a) Background

http://www.acrc.go.kr/en/board.do?command=searchDetail\&method=searchList\&menuId=0 $\underline{20110}$

South Korea ACRC (2016b) Organization

http://www.acrc.go.kr/en/board.do?command=searchDetail\&method=searchList\&menuId=0 $\underline{20113}$

South Korea ACRC (2016c) Mission and Vision

http://www.acrc.go.kr/en/board.do?command=searchDetail\&method=searchList\&menuId=0 $\underline{20116}$

Tanzi, V. (1998) Corruption around the world: causes, consequences, scope, and cures, IMF Economic Review, 45 (4): 559-594

Thailand NACC (2014a) Historical perspective

https://www.nacc.go.th/ewt_news.php?nid=938

Thailand NACC (2014b) Duties of responsibilities

https://www.nacc.go.th/ewt_news.php?nid=937

Thompson, M.R. (1993) The limits of democratisation in ASEAN, Third World Quarterly, 14 (3): $469-484$

Tillyris, D. (2017) Political integrity and dirty hands: compromise and the ambiguities of betrayal, Res Publica, 23 (4): 474-494

Transparency International (2017) People and Corruption: Asia-Pacific - Global Corruption Barometer

https://www.transparency.org/whatwedo/publication/people_and_corruption_asia_pacific_gl obal_corruption_barometer

UNCAC (2005) Convention Against Corruption

https://www.unodc.org/unodc/en/corruption/uncac.html

UN Global Compact (2000) About us https://www.unglobalcompact.org/about

UNODC (2012) Marrakesh Declaration - Conference of the States Parties to the United Nations Convention Against Corruption: conflicts of interest, reporting acts of corruption and asset declarations, particularly in the context of articles 7-9 of the Convention, $22^{\text {nd }}$ June https://www.unodc.org/documents/treaties/UNCAC/WorkingGroups/workinggroup4/2012August-27-29/V1254431e.pdf

US Department of Justice (2016) United States seeks to recover more than \$1 billion obtained from corruption involving Malaysian sovereign wealth fund, $20 \mathrm{July}$, Press Release No. 16-839 https://www.justice.gov/opa/pr/united-states-seeks-recover-more-1-billionobtained-corruption-involving-malaysian-sovereign

US Department of Justice (2017) U.S. seeks to recover approximately $\$ 540$ million obtained from corruption involving Malaysian sovereign wealth fund, 15 June, Press Release No. 17655 https://www.justice.gov/opa/pr/us-seeks-recover-approximately-540-million-obtainedcorruption-involving-malaysian-sovereign 
Walker, T. (2017) Dastyari's downfall and the case for a federal ICAC, Crikey, $12^{\text {th }}$ December https://www.crikey.com.au/2017/12/12/dastyaris-inevitable-downfall-and-thecase-for-a-federal-icac/

Welch, S. (2013) The Theory of Political Culture, Oxford: Oxford University Press

Widojoko, J.D. (2017) Chapter 17: Indonesia's anticorruption campaign: civil society versus the political cartel pp.253-265 in dela Rama \& Rowley (2017) The Changing Face of Corruption in the Asia Pacific: Current Perspectives and Future Challenges, Amsterdam: Elsevier

Winckler, H., \& Doyon, J. (2017) Chapter 11: The limits of anticorruption in China, pp.167177 in dela Rama \& Rowley (2017) The Changing Face of Corruption in the Asia Pacific: Current Perspectives and Future Challenges, Amsterdam: Elsevier

World Bank (2001) Building Institutions for Markets. World Development Report. Washington DC: World Bank

World Bank (2017) Governance and the Law. World Development Report. Washington DC: World Bank Group. Retrieved from http://www.worldbank.org/en/publication/wdr2017

Wright, T. \& Clark, S. (2015) Investigators believe money flowed to Malaysian leader Najib's accounts amid 1 MDB probe, Wall Street Journal, $2^{\text {nd }}$ July https://www.wsj.com/articles/SB10130211234592774869404581083700187014570

Yoo, T. \& Lee, S.H. (2000) In search of social capital in state-activist capitalism: Elite networks in France and Korea, Organization Studies, 30 (5): 529-547 


\section{Charts, Figures and Tables}

\section{Chart 1: National Integrity Ecosystem}

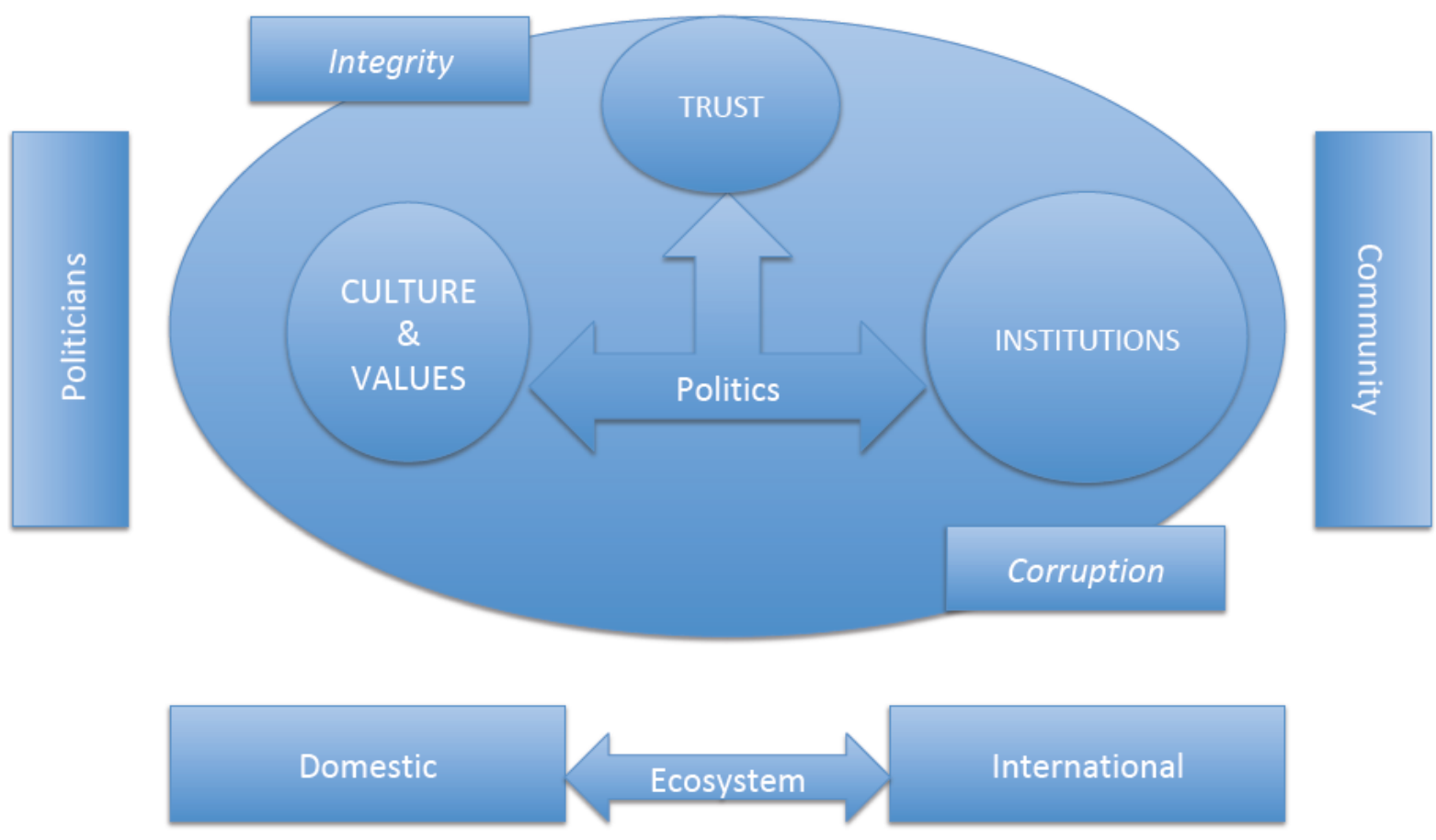

Table 1: List of Six Anti-Corruption Bodies in Five Asia-Pacific Countries

\begin{tabular}{|l|l|l|l|l|}
\hline Country & Name & $\begin{array}{l}\text { Year } \\
\text { Established }\end{array}$ & Remit & $\begin{array}{l}\text { Private Sector } \\
\text { Oversight }\end{array}$ \\
\hline $\begin{array}{l}\text { China } \\
\text { (mainland) }\end{array}$ & $\begin{array}{l}\text { Central } \\
\text { Commission } \\
\text { for Discipline } \\
\text { Inspection } \\
(\text { CCDI })^{5}\end{array}$ & 1978 & $\begin{array}{l}\text { Communist Party } \\
\text { members }\end{array}$ & $\begin{array}{l}\text { Business interests of } \\
\text { Communist Party } \\
\text { members and guanxi } \\
\text { network; international } \\
\text { reach for Party } \\
\text { members with overseas } \\
\text { business interests }\end{array}$ \\
\hline $\begin{array}{l}\text { Hong } \\
\text { Kong } \\
\text { (SAR }\end{array}$ & $\begin{array}{l}\text { Independent } \\
\text { Commission } \\
\text { Against }\end{array}$ & 1974 & $\begin{array}{l}\text { Public officials } \\
\text { including police, and } \\
\text { private sector }\end{array}$ & $\begin{array}{l}\text { Operations department } \\
\text { divided into two: public } \\
\text { and private. Private }\end{array}$ \\
\hline
\end{tabular}

5 China's Central Commission for Discipline Inspection (CCDI) Home Page (in Mandarin), http://www.ccdi.gov.cn accessed $2^{\text {nd }}$ February 2018 


\begin{tabular}{|c|c|c|c|c|}
\hline China) & $\begin{array}{l}\text { Corruption } \\
\text { (ICAC) }^{6}\end{array}$ & & & $\begin{array}{l}\text { sector has its own } \\
\text { director of investigation } \\
\text { and sub-branches } \\
\text { including forensic } \\
\text { accounting and } \\
\text { confiscation of crime } \\
\text { proceeds }{ }^{7} \text {. }\end{array}$ \\
\hline Indonesia & $\begin{array}{l}\text { Corruption } \\
\text { Eradication } \\
\text { Commission } \\
(\mathrm{KPK})^{8} \\
\end{array}$ & 2002 & $\begin{array}{l}\text { Police, electoral } \\
\text { officials, regulatory } \\
\text { officials, politicians }\end{array}$ & $\begin{array}{l}\text { Politicians who are also } \\
\text { businessmen and using } \\
\text { their positions for } \\
\text { personal gain. }\end{array}$ \\
\hline Malaysia & $\begin{array}{l}\text { Anti- } \\
\text { Corruption } \\
\text { Commission } \\
\text { (MACC) }\end{array}$ & 2009 & $\begin{array}{l}\text { Public sector officials } \\
\text { and civil complaints. } \\
\text { Motto is "For the } \\
\text { people; against the } \\
\text { corrupt." }\end{array}$ & $\begin{array}{l}\text { Corrupt transactions } \\
\text { such as bribes between } \\
\text { receivers (nominally } \\
\text { public sector officials) } \\
\text { and givers (nominally } \\
\text { private sector } \\
\text { participants). }\end{array}$ \\
\hline $\begin{array}{l}\text { South } \\
\text { Korea }\end{array}$ & $\begin{array}{l}\text { Anti- } \\
\text { Corruption and } \\
\text { Civil Rights } \\
\text { Commission } \\
(\text { ACRC })^{9}\end{array}$ & 2001 & $\begin{array}{l}\text { Public sector officials } \\
\text { and civil complaints }\end{array}$ & $\begin{array}{l}\text { Limited to "breaking } \\
\text { the chain of corruption } \\
\text { between the private and } \\
\text { public sectors." }\end{array}$ \\
\hline Thailand & $\begin{array}{l}\text { National Anti- } \\
\text { Corruption } \\
\text { Commission } \\
(\text { NACC })^{10}\end{array}$ & 2008 & $\begin{array}{l}\text { Investigate public } \\
\text { sector officials and } \\
\text { "supervise and } \\
\text { observe the ethics of } \\
\text { persons holding } \\
\text { political positions."11 }\end{array}$ & $\begin{array}{l}\text { Business interests of } \\
\text { public officials. }\end{array}$ \\
\hline
\end{tabular}

Figure 1: Private Sector Investigation Unit of HK's ICAC 12

\footnotetext{
${ }^{6}$ HK Independent Commission Against Corruption (ICAC), A Brief History, http://www.icac.org.hk/en/about/history/index.html accessed 2nd February 2018 ${ }^{7}$ HK ICAC, Organization Structure http://www.icac.org.hk/en/ops/struct/index.html accessed 2nd February 2018

${ }^{8}$ Indonesia's Komisi Pemberantasan Korupsi (KPK) Home Page (in Bahasa Indonesia), https://www.kpk.go.id/id accessed 2nd February 2018

${ }^{9}$ South Korea's Anti-Corruption and Civil Rights Commission (ACRC), Home Page, http://www.acrc.go.kr/en/ accessed 2nd February 2018

${ }^{10}$ Thailand's Office of the National Anti-Corruption Commission (NACC), Home Page, https://www.nacc.go.th/main.php?filename=index en accessed $2^{\text {nd }}$ February 2018

"Thailand's NACC, Duties and Responsibilities, https://www.nacc.go.th/ewt news.php?nid=937 accessed $2^{\text {nd }}$ February 2018

${ }^{12}$ HK's ICAC Organizational Structure http://www.icac.org.hk/en/ops/struct/index.html accessed 2nd

February 2018
} 


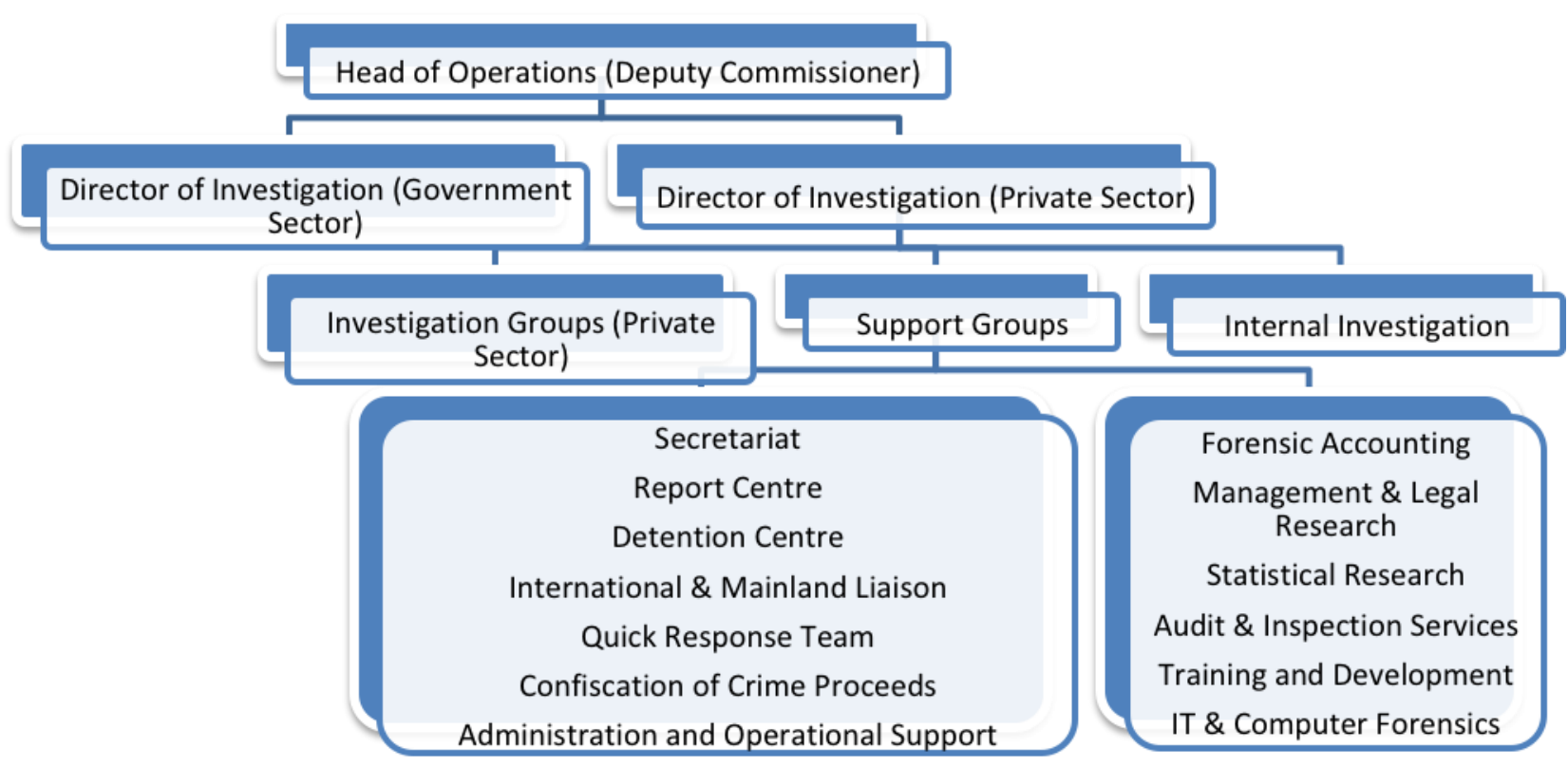

Table 2: History of South Korea's anti-corruption institutions ${ }^{13}$

\begin{tabular}{|l|l|l|}
\hline Year & Name & Remarks \\
\hline July 2001 & Anti-Corruption Commission & Establishment \\
\hline July 2005 & $\begin{array}{l}\text { Korea Independent Commission Against } \\
\text { Corruption }\end{array}$ & Reorganization \\
\hline $\begin{array}{l}\text { February } \\
2008\end{array}$ & $\begin{array}{l}\text { Integrated to "Anti-corruption and Civil } \\
\text { Rights Commission" }\end{array}$ & $\begin{array}{l}\text { Amalgamation of the Ombudsman } \\
\text { of Korea + Korea Independent } \\
\text { Commission Against Corruption }+ \\
\text { The Administrative Appeals } \\
\text { Commission }\end{array}$ \\
\hline
\end{tabular}

${ }^{13}$ We would like to thank our reviewer for explaining this institutional evolution. 
Chart 2: The Australian National Integrity Ecosystem

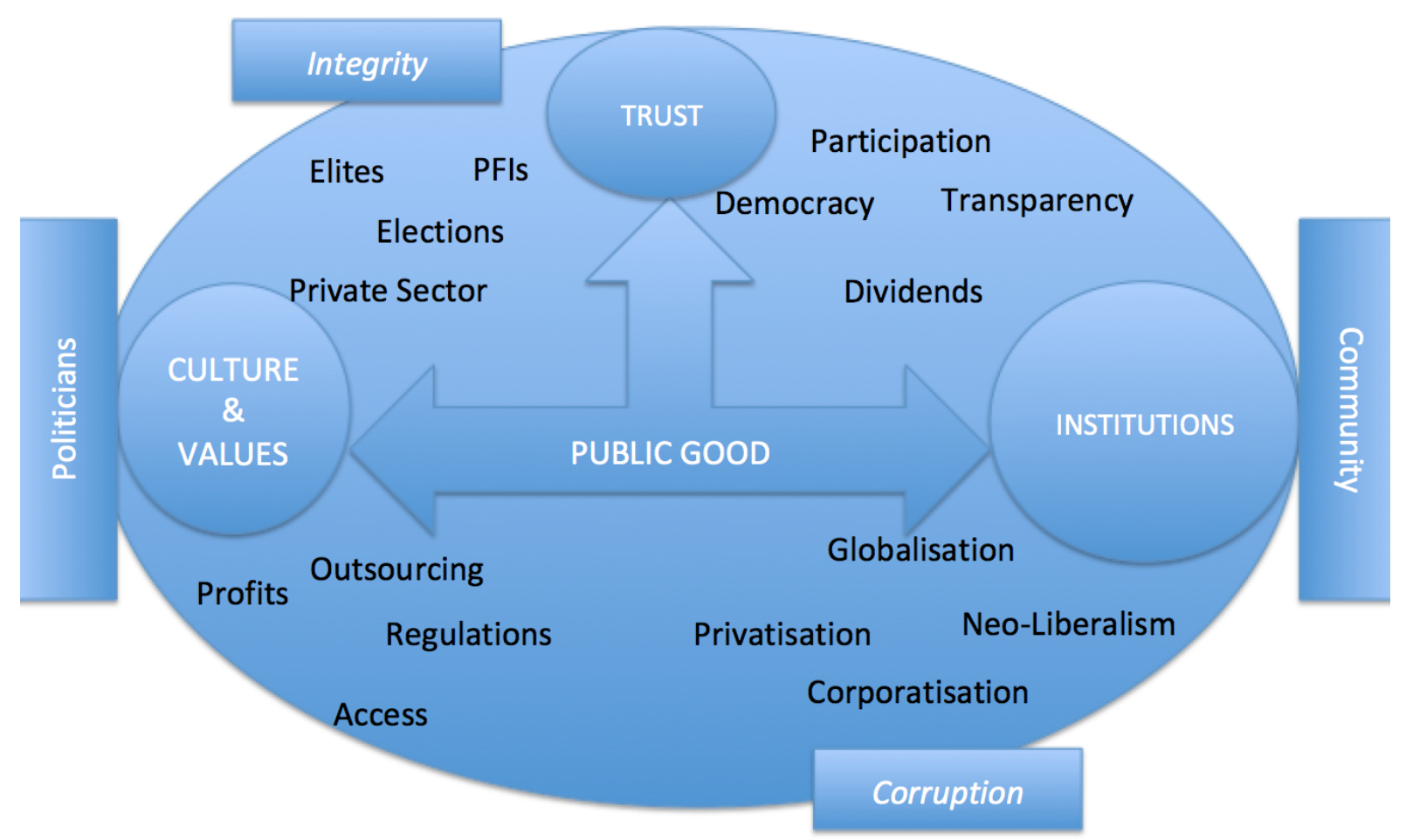

